
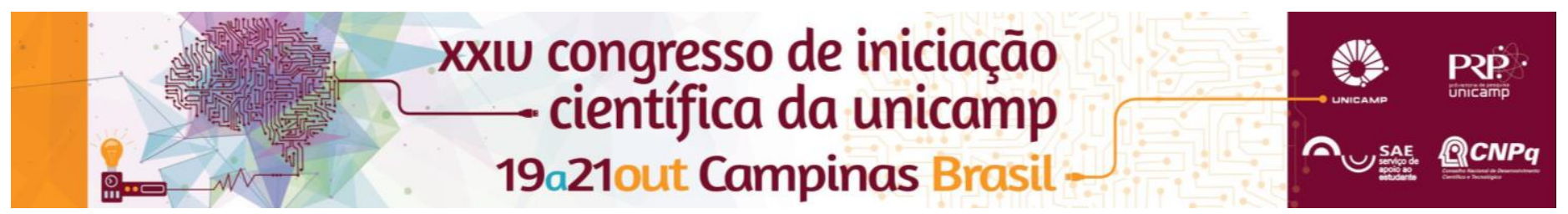

\title{
Proposta do estudo de origem e destino do perfil de cargas da região de Limeira para os Aeroportos de Viracopos e Guarulhos e o Porto de Santos.
}

\section{Guilherme Tellis*}

\section{Resumo}

Este artigo propõe identificar os fluxos de cargas, os pontos de origem considerando três pontos de saída, utilizando a metodologia de pesquisa de natureza aplicada e abordagem qualitativa, com procedimento de pesquisa bibliográfica e levantamento de dados secundários, resultando no impacto que o escopo analisado causa nos pontos de saídas para exportação.

\section{Palavras-chave:}

Fluxo de Cargas, Intermodalidade, Logística.

\section{Introdução}

O Porto de Santos, o maior da América Latina mais uma vez fortalece sua posição de principal canal de entrada e saída do mercado exterior do Brasil. No ano de 2015 o porto santista teve participação de $27,4 \%$ do total brasileiro, representando um aumento compara ao ano de 2014 em que sua participação foi de 25,4\% (Assessoria de comunicação social. Porto de Santos, 2015).

Como a dispersão das áreas indústrias das capitais para o interior cria-se novos elos de suprimentos e rotas para o abastecimento dessas cadeias, com o intuito de acelerar o processo de abastecimento dos mercados. Identificar os fluxos de origem e destino e os materiais que são transportados pode auxiliar na tomada de decisão na hora de escolher o sistema de modais de transportes que melhor atenda o custo benefício para as empresas. O objetivo deste trabalho é avaliar o fluxo de cargas de exportação da mesorregião de Piracicaba com destino aos aeroportos de Viracopos e Guarulhos e ao porto de Santos para identificar as características que influenciam o resultado da movimentação da carga.

\section{Resultados e Discussão}

A pesquisa se classifica como de natureza aplicada e abordagem qualitativa (KUARK; MANHÃES; MEDEIROS, 2010), tendo como origem a macrorregião de Piracicaba totalizando 26 municípios. Os aeroportos de Viracopos localizado em Campinas e o de Guarulhos localizado em São Paulo não tiveram seus dados divulgado, devido se tratar de aeroportos que estão sob concessão privada desde o ano de 2012 desta forma foi realizada somente uma análise mais detalhada do Porto de Santos.

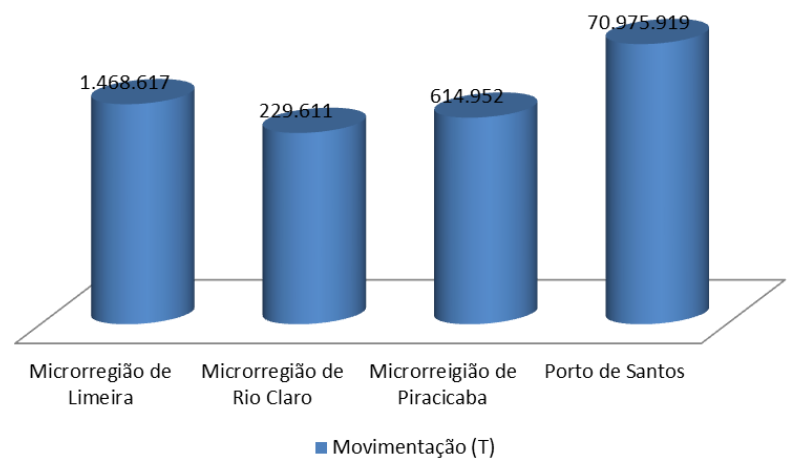

Figura 1: Movimentação entre Microrregiões e o Porto de Santos

DOI: 10.19146/pibic-2016-50915
Pela movimentação de cargas através do Sistema Harmonizado (SH2) dentro da mesorregião, os produtos com maior movimentação em tonelada são da seção XVIII, com 530.800 toneladas movimentadas o que representa $22,97 \%$ do total exportado, seguidos dos produtos da seção IV com 504.465 toneladas representado $21,80 \%$ do total dos produtos e das seções II e X em seguidas com 374.303 (16,18\%) e 250.951 $(10,85 \%)$ respectivamente sendo essas as quatro classificações que representam mais de $70 \%$ das mercadorias exportadas pela mesorregião.

Em relação a valor agregado em exportação da mesorregião com o total de US\$ 2.775.950.925,00 a microrregião de Piracicaba se destaca por ser responsável com $57 \%$ deste faturamento exportando o total de US\$1.596.151.319,00 ficando em seguida as microrregiões de Limeira e Rio Claro com 36\% e 7\% respectivamente.

Os principais destinos das mercadorias do Estado são para os continentes da Ásia e Europa totalizando mais de $74 \%$ das cargas enviadas para o exterior.

\section{Conclusões}

A Mesorregião de Piracicaba tem um comércio de exportação ativo e com baixo impacto no porto de Santos, o que mostra oportunidade na expansão do comércio internacional. Aponta uma movimentação com forte exportação de produtos das seções XVIII, IV, II e X.

Mostra ainda uma forte dependência do modal rodoviário para o transporte de mercadorias interna e abra a possibilidade de se aplicar mais a intermodalidade de transporte com o intuito de aproveitar o melhor de cada transporte e a possibilidade de reduzir custos e aperfeiçoar o sistema logístico nacional, criando a possibilidade de expansão da multimodalidade quando possível desafogar o trafego de rodovias veículos pesados nas rodovias estaduais e nacionais.

\section{Agradecimentos}

Gostaria de Agradecer a Universidade Estadual de Campinas, e ao SAE (Sistema de Apoio ao Estudante) pelo apoio e financiamento na realização da pesquisa, e ao Laboratório LEGOS da FCA/UNICAMP

KAUARK, F.;MANHÃES, F. C.; MEDEIRAOS, C. H. (2010) Metodologia da pesquisa: guia pratico, Via Litterarum, Itabuna.

Acessória de Comunicação Social. Porto de Santos (2015). Disponível em:

<http://www.portodesantos.com.br/pressRelease.php?idRelease $=882>$. Acessado em 30 de abril de 2016.

XXIV Congresso de Iniciação Científica da UNICAMP 